Globish (An English-Indonesian journal for English, Education and Culture)

Vol. 11, No.1, January 2022,

P-ISSN: 2301-9913, E-ISSN: 2597-9132

DOI: http://dx.doi.org/10.31000/globish.v7i2

\title{
SOURCE AND TARGET LANGUAGE OREINTED ON THE BICYCLE RIDER BY TOM W. SHAPCOTT ON SAPARDI DJOKO DAMONO'S TRANLSATION (A CASE STUDY)
}

\section{${ }^{1}$ Eka Ugi Sutikno, ${ }^{2}$ Praksi Kurniawan, ${ }^{3}$ Onny Bisma Dwi Nugroho, ${ }^{4}$ Nina Alfah, ${ }^{5}$ Erien Rida Winarti, ${ }^{6}$ Vinanda Audria, ${ }^{7}$ Kamelia}

1,2,3,4,5,6, 7 English Education Study Program

Muhammadiyah University of Tangerang

Jl.Perintis Kemerdekaan I/33 Cikokol, Tangerang-Indonesia

E-mail: ekaugisutikno@umt.ac.id,praksikurniawan29@gmail.com, onnybdn01@gmail.com, ninaalfahsagita102@gmail.com, erienwinarti04@gmail.com,vinandaaudria1707@gmail.com, amelkamelia61@gmail.com

\begin{abstract}
The cultural differences between English and Indonesian languages impact the language used if vice versa, translations should suffice. The translation is a result of the distinctions outlined. This article aims to analyze the source and target Language oriented on The Bicycle Rider by Tom W. Shapcott on Sapardi Djoko Damono's Translation. This approach is structured based on the topic matter and the study's primary purpose. Data collection, analysis, and research design are part of this study's methodology. To analyze The Bicycle Rider by Tom W. Shapcott on Sapardi Djoko Damono's translation, we use Newmark's theory as the base thinking. In this translation, we found six free translation methods, five semantic translation methods, five literal translation methods, and two adaptation translation methods. The conclusion is that this translation has dominated by source language-oriented translation; meanwhile, it has some target language-oriented translation.

Keywords: source language, target language, poem translation

\section{INTRODUCTION}

The translation is a significant phenomenon that has a considerable impact on daily life. The translation is necessary since it initiates communication and prevents misunderstandings between languages. The objective of translation theory is to understand the processes involved in translation, not to establish a set of standards for achieving the ideal translation, as is sometimes misunderstood. Translation, in general, is the process of conveying an idea, information, or purpose from the Source Language (SL) to the Target Language (TL). Catford describes translation as an operation on languages: the process of replacing one language's text for another's text. Translation is a skill that entails attempting to replace a written message and statement in one language with the identical transmission and information in another (Newmark, 1988, 1993). The translation activity consists of two components: SL, the language the work translates, and TL, or the language the translator will organize (Newmark, 1977). The objective of translation is to recreate different types of spoken or written documents in another language, increasing their accessibility to a broader audience. The translation is a process of information transmission that tries to convert a written SL text into an ideally comparable TL text. It requires a comprehension of the SL's syntax, semantics, and pragmatics, as well as analytical processing.
\end{abstract}


Globish (An English-Indonesian journal for English, Education and Culture)

Vol. 11, No.1, January 2022,

P-ISSN: 2301-9913, E-ISSN: 2597-9132

DOI: http://dx.doi.org/10.31000/globish.v7i2

The translation is not a simple skill to acquire; it entails switching messages from SL to TL. In addition, people should know the numerous factors of these. Various nations speak different languages, but they also have distinct cultures. Translation, scholars argued, could be used to spread a nation's culture, technology, and philosophies to other countries with other languages. The many and challenging characteristics of translation - such as form, meaning, equivalent, proverbs, style, and idiom - between SL and TL and the cultural differences between them make the process of translation a little bit more complicated.

The English and Indonesian languages are culturally distinct, which affects the language employed (Dewi \& Hidayat, 2020). Numerous translations from English to Indonesian and vice versa should accomplish (Fitria, 2018). As a result of the distinctions discussed above, translation requires. The translation is a broad term that refers to the process of transferring a message or meaning from one language to another, which translation is the process of moving message or meaning from one language to another. Then the translation result must correspond with the source text, whether it is equal or not.

As a professional linguist and Bible translator, the translator had enormous influence and demonstrated the critical nature of textual and cultural connection in translation efforts (Millar, 2020). Additionally, translation enables cross-cultural contact in today's culture by turning one language into another (Zain et al., 2019). Otherwise, dynamic equivalent translation refers to how messages included in the original text are transmitted. Those who read or hear the transferred message are identical to those who read or hear the original text.

Not only does translation entail the source and target languages, but also the source and target cultures. The translation is, in essence, a bicultural endeavor. The translator creates a symbiotic relationship between the source and destination cultures via translation. The translator needs to be fluent in two languages; they must also grasp both cultures(Lomas, 2018). When the translator begins transferring the message, they must exercise caution in identifying the source language in the target language. They must recognize the distinctions between the source and target languages and, as a result, must place an equivalent in the target language that is both appropriate and has the same meaning as the source language (Coppers et al., 2018; Läubli et al., 2018). They must locate an equal in the target language, but another issue encountered during the translation process may result in an erroneous, unacceptably long, or illegible translation.

The translator must contend with two distinct languages conveyed via words, phrases, clauses, and sentences throughout the translation process. The translator's first focus should be on finding analogies in the target language. One factor that makes it difficult for a translator to provide an accurate translation is the distinct grammatical structures of the source and destination languages (Kaharuddin, 2018; Spahiu \& Kryeziu, 2021). The differences between the source and destination languages' grammatical structures often alter the message's information content throughout the translation process (Nugraha et al., 2017). For instance, the English and Indonesian grammatical structures are opposed.

On the other hand, there are distinctions between literary and nonliterary works regarding translation. Literary works are concerned with the imaginative world, concentrate on the human person, and occasionally mirror their physical qualities and natural and climatic environment (Jizzakh \& Mamasharif, 2020; Tian \& Zhu, 2020). The vocabulary term' literary work' may be defined as imaginative or creative writing, which indicates that literary work is the writer's labor, anything stated in letters, and any writer's movement that can be imaginative if the writer desires (Blokh et al., 2019). Literary works come in various forms, including poetry, fiction, and song. Literary works are differentiated from nonliterary works by their symbolic or allegorical nature. The most significant emphasis is on connotation (Sutikno, 2019, 2021a) and emotion when translating an academic work, particularly in creative writing. 
Globish (An English-Indonesian journal for English, Education and Culture)

Vol. 11, No.1, January 2022,

P-ISSN: 2301-9913, E-ISSN: 2597-9132

DOI: http://dx.doi.org/10.31000/globish.v7i2

A translator might choose from various translation tasks based on their expertise. One kind of translation that a translator may choose based on their interests. A particular type of translation is on in literary writings. Poems are a subset of literary works because literary works include poetry (Sutikno, 2021b), this research focuses on literary translation. The fundamental objective of translation is to make a message that originated in one language accessible to those familiar with that language. By translating a source work, such as a poem, many people may read it in their language and comprehend the poems' or literary works' substance.

Reduced adjustments, additions, and modifications to the essential aspect of Indonesian poetry are often inevitable while translating the poems. Not all words can be translated directly from the source to the target language when dubbed a poem. To ascertain the modifications made to Australian poetry, we may compare (analysis) between the English The Bicycle Rider) and Indonesian (Pengayuh Sepeda) versions of the poem (Shapcott, 1991). This article discussed The Bicycle Rider by Tom W. Shapcott, which Sapardi Djoko Damono translated as 'Pengayuh Sepeda.' In his translation has free translation methods, semantic translation methods, literal translation methods, and adaptation translation methods. These methods seem natural as the translation work to be the target language.

\section{THEORETICAL FRAMEWORK}

Understanding the source language text's vocabulary, grammar, and cultural context is the first step in translating it into the target language's lexicon and grammatical structure, suited to its context (Zbib et al., 2019). Put another way, and it implies that translation will continue to serve as a bridge between people worldwide.

The translation Understanding the source language text's vocabulary, grammar, and cultural context is the first step in translating it into the target language's lexicon and grammatical structure, suited to its context (Zbib et al., 2019). Put another way, and it implies that translation will continue to serve as a bridge between people worldwide.

The translation is critical in emerging nations like Indonesia to get information and technology as an interlingual communication activity (Newmark, 1977). Students may better understand scientific concepts because the university includes translation as a course option. Translation acts as a bridge between SL and TL, bridging the gap between languages and cultures.

Scientists will not keep up with scientific developments if they do not translate. As a result, translation is critical for both emerging nations and wealthy nations. If a country needs translation, this does not mean that it is a developing nation. However, exchanging information from one government to another is a legitimate activity.

The translation of official documents, such as treaties and contracts, is increasingly common in public places. Natives from the native language often produce national pride in the "foreign" language. The translation uses other multilingual notices, such as reports, papers, articles, correspondence, textbooks, to convey information and advice that have recently become increasingly noticeable in public places. Some individuals also use translated books to learn a foreign language since they are more straightforward to comprehend than the original literature. When it comes to teaching and learning, translation is an important activity that many colleges across the globe include in their curriculums. The translation method is a technique employed in teaching foreign languages (House \& Juliane, 2018; Iordan, 2021). The underlying assumption of this technique is that mastery of foreign languages may attain via activities involving the translation of languages taught in the students' native tongue. The primary exercise in this system is the practice of this translation.

Methods of translation as to how a particular translation process is carried out in terms of the translator's objective, i.e., a global option that affects the entire text (Newmark, 1977, 1988,

Received December 10, 2021; Revised December 25, 2021; Accepted December 28, 2021 
Globish (An English-Indonesian journal for English, Education and Culture)

Vol. 11, No.1, January 2022,

P-ISSN: 2301-9913, E-ISSN: 2597-9132

DOI: http://dx.doi.org/10.31000/globish.v7i2

1993). In contrast, translation procedures apply to sentences and other smaller language units. It may infer that the translators' translation techniques affect the outcome of translated writings since their purpose and goal will influence the overall outcome of their translated documents. Translation approaches into two categories: SL emphasis, which includes word-for-word translation, literal translation, and faithful translation, and TL emphasis, which includes adaptation, free translation, idiomatic translation, and communicative translation (Newmark, 1988).

Word-for-word translation. The interlinear translation is a pre-translation technique in which the TL words are placed precisely below the SL ones (Dinarty, 2019; Newmark, 1988). The translations of cultural terms are based only on their literal meanings. It is only necessary for translators to locate SL-to-TL equivalents, but the location of those SL words stays intact in TL so that the mechanism of TL may be understood.

Example:

SL: She is laughing.

TL: Ia sedang tertawa.

Literal translation. Instead of translating word-for-word, this approach uses the grammatical structure of TL to determine where the words should be put in the text, rather than translating them word-for-word (Bell, 1993; Newmark, 1988). The SL grammatical forms translate into their closest target language equivalents. On the other hand, the lexical terms translated about context.

Example:

SL: I think this problem is a piece of cake.

TL: Menurutku masalah ini adalah potongan kue.

Faithful translation. Translators use the grammatical structure of TL to position their translations to achieve an accurate translation. Even though cultural terms translate, grammatical and lexical anomalies persist (Newmark, 1988; Robinson, 2012). In this context, 'faithful' is a translation effort to be as accurate as possible to the original SL author's objectives and wording.

Example:

SL: I am eating dinner with her.

TL: Aku sedang makan malam bersamanya.

Semantic translation. The aesthetic factor considered in semantic translation and cultural terms in SL are translated into their cultural equivalents in TL, making this process more natural. In contrast, semantic translation is more flexible (Bell, 1993; Newmark, 1988).

Example:

SL: She belongs to a man.

TL: Ia sudah punya pacar.

Adaptation translation. As 'the freest form of translation,' adaption utilizes in translating poetry and the script of plays in which cultural changes occur from the source language (SL) to the target language (TL) (Newmark, 1988; Rahma et al., 2018). Translators have to keep the 
Globish (An English-Indonesian journal for English, Education and Culture)

Vol. 11, No.1, January 2022,

P-ISSN: 2301-9913, E-ISSN: 2597-9132

DOI: http://dx.doi.org/10.31000/globish.v7i2

characters and narrative intact while translating a play's script, for example, so that they can only change the script's dialogue.

Example:

SL: Bengawan Solo

Riwayatmu ini

Sedari dulu jadi...

Perhatian insani

TL: Bengawan Solo

River of love, behold

Where the palms are swaying low

And lovers get so enthralled (Pan, 2012)

Free translation. It is usual to utilize paraphrases to ensure that the source text's meaning may convey to readers of the target text, as in this manner. Known as 'creative translation,' this service does not always pay close attention to the original text's finer points but maintains the overall meaning and sound of the translation (Newmark, 1988). They must be innovative and knowledgeable about the cultures in both languages they are translating. Marketers, advertisers, and authors often use this kind of translation.

Example:

SL: Make yourself comfortable.

TL: Santai saja.

Idiomatic translation. Since the message is duplicated in TL using more natural and familiar terms employing colloquialisms and idioms that do not exist in SL, translations will no longer sound like translations (Newmark, 1988; Zahrani, 2018). When translating from one language to another, idiomatic translation attempts to preserve as much of the original meaning as possible, resulting in a loss of subtlety.

Example:

SL: My eye is hard on you

TL: Kau tak pernah kulupakan.

Communicative translation. In this strategy, translations are prioritized based on their intended audience and the purpose of translation (Newmark, 1988). Since users of TL anticipate no difficulty in reading translated literature, translators must translate SL's contextual meaning, both its language and its content.

Example:

SL: Caution. Wet floor.

TL: Hati-hati. Lantainya basah.

The translator may encounter a linguistic, literary, artistic, and socio-cultural challenge in translating literary works. Collocation and insured are two of the language issues that need plead. Literary and aural difficulties develop when the translator translates expressions encompassing the four primary cultural categories, including ideas, ecology, behavior, and goods; these connect to aesthetic and literary issues. Because literary works have distinct aesthetic and expressive characteristics, translating them is likely more challenging than 
Globish (An English-Indonesian journal for English, Education and Culture)

Vol. 11, No.1, January 2022,

P-ISSN: 2301-9913, E-ISSN: 2597-9132

DOI: http://dx.doi.org/10.31000/globish.v7i2

translating other kinds of materials. Using figurative language, metaphors, and other literary devices to enhance the work's artistic value is essential to the project's success. On the other hand, the expressive function is responsible for conveying the thoughts and feelings of the writer. Furthermore, the translator must make every effort to convey these particular values in the target language.

\section{RESEARCH METHOD}

Using a research methodology is a methodical strategy to achieving the study's primary objective. This approach is structured based on the topic matter and the study's primary purpose. Data collection, analysis, and research design are all part of this study's methodology. It uses a library catalog (House \& Juliane, 2018; Iordan, 2021) to find the information he needs. The data acquired in the unit analysis by explained using a descriptive method based on relevant theory and examples.

As part of this project, the translation of poems by meticulously documented; consequently, the writer collected and processed the data and identified Sapardi Djoko Damono's translation procedures for Tom W. Shapcott's poetry in Bahasa Indonesia, which he applied. Finally, the author studied and classified the translation strategies used in that translation's poems.

\section{RESULT AND DISCUSSION}

This poem tells about a father who just bought a bicycle; then, his son was delighted to see his father carrying the new bike (perhaps actually, the bike was not for him). He immediately asked his father to learn to ride the new bicycle; after that, he began to feel nervous because many children followed him when he was learning to play a bike. His father taught his son to play a bicycle while going around the park for three rounds, his father too. He began to feel tired and tired after this father remembered his past that he was good at playing bicycles as a child.

His son became as good as his father until he did not feel the road was damaged. The father and son finally decided to go home, and they both started racing bicycles, starting from the park to the house. On the way, his father told his son to go through a good road because every road is another option, and the father was proud of himself and his son that someone would continue his hobby. Now they both have arrived home, and their sweat is already sweating and dripping profusely like a sweat bath after coming home from playing bicycles together in the park until going around the park three times.

\section{The Bicycle Rider \\ Tom W. Shapcott}

Just like that. When he brings the new bike home

his son is all legs with excitement. 'No, it's for me.'

'Go on, dad, ride it outside.' He knows how clumsy he will be, first time. The boys race after him, professionals in the district. 'Do a sleewie.' They aim for the park and circle it three times. He is aching already - all this crazy industry

\section{Pengayuh Sepeda \\ Tom W. Shapcott}

Begitu saja. Ketika lelaki itu membawa pulang sepeda baru

anak laki-lakinya melonjak gembira. 'Tidak, ini buatku.'

'Ayo, Yah, naiki di luar.' Lelaki itu tahu betapa kikuk

ia, mula-mula. Anak-anak mengikutinya, mereka itu jagoan naik sepeda. 'Mainkan, Yah.' Mereka

ke taman dan berputar tiga kali. Ia sudah merasa pusing - kesintingan yang bikin capek ini 
Globish (An English-Indonesian journal for English, Education and Culture)

Vol. 11, No.1, January 2022,

P-ISSN: 2301-9913, E-ISSN: 2597-9132

DOI: http://dx.doi.org/10.31000/globish.v7i2

\begin{tabular}{|c|c|}
\hline $\begin{array}{l}\text { for the sake of sagging gut and remnant of } \\
\text { dream! } \\
\text { If he had forgotten how you feel each bump } \\
\text { and rise, } \\
\text { he is not a clerk, now, he feels as the boy feels; } \\
\text { every street } \\
\text { is an alternative. 'Come this way, dad.' Sweet } \\
\text { indeed to become a novice in your son's eyes. } \\
\text { It's a race for home. How long can this go on? } \\
\text { The sweats creeps out on his forehead, it } \\
\text { scatters in the sun. }\end{array}$ & $\begin{array}{l}\text { hanya demi perut buncit dan sisa mimpi! } \\
\text { Jika ia sudah lupa rasanya jalanan yang } \\
\text { benjol-benjol, } \\
\text { itu lantaran ia bukan berani, kini ia merasa } \\
\text { seperti yang } \\
\quad \text { dirasakan seorang anak laki-laki; } \\
\text { setiap jalan adalah pilihan. "Lewat jalan ini, } \\
\text { Yah.' Sungguh } \\
\text { senang jadi orang yang baru belajar di mata } \\
\text { anak sendiri. } \\
\text { Ini balapan pulang. Berapa lama ini bisa } \\
\text { berlangsung? } \\
\text { Peluh menetes di dahinya, berhamburan di } \\
\text { matahari. }\end{array}$ \\
\hline
\end{tabular}

(Shapcott, 1991)

SL: The Bicycle Rider

TL: Pengayuh Sepeda

Grammatical constructions seek closer equivalents in the SL in the literal translation method, but the linguistic translation or the words are carried out separately from the context. In the early stages of the translation process, this method can see problems that need to address immediately. This method is still the same as the previous word for word, namely matching, which is still out of context. This method can also use as a first step in doing a translation. The difference only lies in the grammatical construction of $\mathrm{TL}$, which is trying to be changed to approach the grammatical structure of SL.

\section{SL: Just like that.}

TL: Begitu saja.

It uses the semantic translation method. The difference between semantic translation and faithful translation is that in addition to paying more attention to SL's aesthetic value and fairness, it also compromises the level of meaning when necessary. Furthermore, only slightly charged words translate with neutral or functional terms in semantic translation. In summary, the difference between the two is that faithful translation is uncompromising and dogmatic. In contrast, semantic translation is more flexible, providing space and empathy for the translator's intuition towards TL.

SL: When he brings the new bike home his son is all legs with excitement.

TL: Ketika lelaki itu membawa pulang sepeda baru anak laki-lakinya melonjak gembira.

The translator used the semantic translation method because it is more flexible than faithful translation. The product of faithful translation is more rigid and uncompromising with the rules of the target language or tied much to the source language. In contrast, semantic translation is more flexible because of the 'faithful method' in reproducing words in the target language. Semantic translation considers the aesthetic elements of the source language (SL) by 
Globish (An English-Indonesian journal for English, Education and Culture)

Vol. 11, No.1, January 2022,

P-ISSN: 2301-9913, E-ISSN: 2597-9132

DOI: http://dx.doi.org/10.31000/globish.v7i2

compromising the meaning as long as it is within the limits of reasonableness. In the example above, the phrase 'all leg with excitement' was translated flexibly according to the target language's cultural context and acceptable functional limits. However, the correct translation should be' semua kaki terlihat gembira.'

SL: $\quad$ 'No, it's for me.' 'Go on, dad, ride it outside.'

TL: 'Tidak, ini buatku.' 'Ayo, Yah, naiki di luar.'

Literal Translation method, In the process of translation, translators look for grammatical constructions of the source language that match too, equivalent with or close to the target language. This translation method detaches from the context. This method carries out a word-for-word translation, but the translator then adjusts the arrangement of his words according to the target language's grammar.

The phrase 'no, it's for me' has been translated according to the Indonesian phrase structure into 'Tidak, ini buat aku' and the sentence 'Go on, Dad. Ride it outside' has been translated into 'Ayo Yah, Mengendarainya di luar' is quite well and acceptably.

SL: He knows how clumsy he will be, first time.

TL: $\quad$ Lelaki itu tahu betapa kikuk ia, mula-mula.

The free translation method is a free translation method that reproduces the general meaning of the original text in the target text and may or may not closely follow the form of the original text. We can take 'Clumsy,' which translates to 'Kikuk,' with different meanings. This free translation is not bound to the equivalent searching of a word or expression but for the equivalent more emphasized on a broader level than the sentence.

SL: The boys race after him, professionals in the district.

TL: $\quad$ Anak-anak mengikutinya, mereka itu jagoan naik sepeda.

The translator used the semantic translation method because it is more flexible than faithful translation. The product of the faithful translation is more rigid and uncompromising with the rules of the target language or tied much to the source language. In contrast, semantic translation is more flexible because of the 'faithful method' in reproducing words in the target language. Semantic translation considers the aesthetic elements of the source language (SL) by compromising the meaning as long as it is within the limits of reasonableness. In the example above, the phrase 'The boy race after him' was translated flexibly according to the target language's cultural context and acceptable functional limits.

SL: 'Do a sleewie.'
TL: 'Mainkan, Yah.'

The sentence 'do a slewie' using the free translation method, In the word 'slewie' is not grammatically appropriate. The term 'slewie' has many meanings. Translators interpret it as 'play' and, in essence, 'slewie' can be interpreted as 'do a guide (freestyle).' In the free translation, the result of the application is usually in the form of a more extended paraphrase or has several other meanings from the original state. Free translation methods prioritize the content of TL rather than the form of its structure. Freedom in this method is still limited to being free to express meaning in SL so that the purpose or content of TL is still limited even though the form 
Globish (An English-Indonesian journal for English, Education and Culture)

Vol. 11, No.1, January 2022,

P-ISSN: 2301-9913, E-ISSN: 2597-9132

DOI: http://dx.doi.org/10.31000/globish.v7i2

of TL text is not reappearance. Furthermore, the search for equivalents also tends to be at the text station, not words, phrases, clauses, or sentences, so that it will seem like paraphrasing TL.

SL: $\quad$ They aim for the park and circle it three times.

TL: $\quad$ Mereka ke taman dan berputar tiga kali.

They choose semantic translation over 'faithful' translation because it is adaptable. The outcome of faithful translation is more rigid and unbending in its adherence to the target language's laws or is inextricably linked to the source language, whereas semantic translation is more flexible due to the 'faithful' method of word reproduction in the target language. Semantic translation considers the aesthetic qualities of the source language (SL) by compromising the meaning to a fair extent.

Using the semantic approach, the true meaning followed by the 'They' equals 'mereka,' 'aim' equals 'bermaksud,' 'for the park' equals 'ke taman,' 'and circle it' equals 'dan memutari itu,' 'three times' equals' tiga kali.' The case above can be omitted and replaced with "They went to the park and circled three times."

SL: $\quad$ He is aching already

TL: $\quad$ Ia sudah merasa pusing

Literal Translation Method, In the process of translation, translators look for grammatical constructions of the source language matching to, equivalent with or close to the target language. This translation method disjoint from the context. This method takes out and like word-for-word translation, but the translator then adjusted the arrangement of his words according to the target language's grammar.

He is using the literal method. Details: 'He' equals 'dia.' 'aching' equals 'sakit.' 'already' equals 'sudah.' By literally re-adjusting the arrangement, it means that this person already feels sick case, because going around the garden makes him dizzy.

SL: - all this crazy industry for the sake of sagging gut and remnant of dream!

TL: $\quad$ - kesintingan yang bikin capek ini hanya demi perut buncit dan sisa mimpi!

The free translation method is a free translation method that reproduces the general meaning of the original text in the target text and may or may not closely follow the form of the original text. We can take the example of the sentence' Sagging gut,' which translates to 'Perut buncit,' both of which have a meaning that is not much different, 'free translation' is a type of translation that untied to the equivalent searching of words or expression but for the equivalent more emphasized on a broader level than the sentence.

SL: If he had forgotten how you feel each bump and rise,

TL: Jika ia sudah lupa rasanya jalanan yang benjol-benjol,

It uses the free translation method because the Free translation method is a translation that reproduces the general meaning of the original text in the target text and may or may not closely follow the form of the original text. Using free translation method, with details: 'if he had' equals 'jika ia sudah,' 'forgotten' equals 'lupa,' 'how you feel' equals 'bagaimana kamu merasakan,' 'each bump' equals 'setiap benjolan,' 'raise' equals 'kenaikan/naik.' 
Globish (An English-Indonesian journal for English, Education and Culture)

Vol. 11, No.1, January 2022,

P-ISSN: 2301-9913, E-ISSN: 2597-9132

DOI: http://dx.doi.org/10.31000/globish.v7i2

SL: he is not a clerk,

TL: itu lantaran ia bukan berani,

It uses Adaptation Translation Method because adaptation is the most complimentary translation method that leads to the closest equivalence of the target language. Indeed, this translation method maintains the source language and prioritizes target readers. Though the term is 'adaptation,' it does not mean sacrificing the theme, character, or plot. If so, it is not adaptation but creation. Adaptation is widely employed to translate poetry and drama. There is a culture transition of the source language (SL) to the target language (TL), and the source text is rewritten and adapted to the target text.

Using the adaptation method Because the word 'clerk,' translated as 'kerani,' has a reasonably close meaning, namely 'scribe/staff,' 'Kerani' itself has another meaning, namely someone in the field of administration.

SL: now, he feels as the boy feels;

TL: kini ia merasa seperti yang dirasakan seorang anak laki-laki

Using the literal translation method, translators look for grammatical constructions of the source language matching to, equivalent with, or close to the target language. This translation method detaches from the context. This method assumes the word-for-word translation, but the translator adjusts his words according to the target language's grammar.

Using the literal method because the sentence "Now, he feels as the boys feel' which translates as 'seperti yang dirasakan anak laki laki' has the same meaning as SL.

SL: every street is an alternative.

TL: $\quad$ setiap jalan adalah pilihan.

It uses Adaptation Translation Method because adaptation is the most complimentary translation method that leads to the closest equivalence of the target language. Indeed, this translation method maintains the source language and prioritizes target readers. Though the term is 'adaptation,' it does not mean sacrificing the theme, character, or plot. If so, it is not adaptation but creation. The adaptation uses to translate poetry and drama. There is a culture transition of the source language (SL) to the target language (TL), and the source text is rewritten and adapted to the target text. It uses the adaptation method Because the word 'Alternative' translated onto 'Pilihan' has reasonably close.

SL: 'Come this way, dad.'

TL: 'Lewat jalan ini, Yah.'

The translator uses the semantic translation method. It is a more flexible translation method than faithful translation. The product of 'the faithful translation' is more rigid and uncompromising with the rules of the target language or tied much to the source language. In contrast, semantic translation is more flexible than 'the faithful method' in reproducing words in the target language. Semantic translation considers the aesthetic elements of the source language (SL) by compromising the meaning as long as it is within the limits of reasonableness. The translator uses 'lewat' instead of coming because the father is riding a bicycle, and the child shows the way. 
Globish (An English-Indonesian journal for English, Education and Culture)

Vol. 11, No.1, January 2022,

P-ISSN: 2301-9913, E-ISSN: 2597-9132

DOI: http://dx.doi.org/10.31000/globish.v7i2

SL: Sweet indeed to become a novice in your son's eyes.

TL: Sungguh senang jadi orang yang baru belajar di mata anak sendiri.

The free translation method uses in the 'Sweet Indeed' section. Because the word sweet indeed has a true meaning, namely 'sweet,' while it becomes thrilled in the translated book, the sentence becomes a longer paraphrase than the original. The work intends that the content or message from the author of the source text will accept by the target language used so that the translation looks lined and long-winded; even the translation looks like it is not a translation. This translation can also be called Intra-lingual translation. This free translation method prioritizes content and sacrificing more form. Free translation is only in the SL message; this does not adjust to the TL culture with the TL culture. The section "To become a novice in your son's eyes' uses the semantic method because 'to become' means 'jadi,' 'a novice' means 'pemula.' In contrast, translators use the translation 'people who are just learning, 'in your son's eyes' means 'di mata anak laki-lakimu,' while the translator uses the translation 'di mata anak sendiri.'

SL: It's a race for home. How long can this go on?

TL: Ini balapan pulang. Berapa lama ini bisa berlangsung?

Literal method, In the process of translation, translators look for grammatical constructions of the source language matching to, equivalent with, or close to the target language. This translation method is severe from the context. This method carries onto like word-for-word translation, but the translator then adjusted the arrangement of his words according to the target language's grammar. Using the literal method because the sentence "How long this can go on?' translates as 'Berapa lama ini bisa berlangsung' has the same meaning as SL.

SL: The sweats creeps out on his forehead, it scatters in the sun.

TL: Peluh menetes di dahinya, berhamburan di matahari.

It uses the free translation method because it is a translation that reproduces the general meaning of the original text in the target text and may or may not closely follow the form of the original text. We can take the example of the sentence 'The sweats creeps out on his forehead,' which translates to 'peluh menetes di dahinya' both of which have a meaning that is not much different. Free translation is a type of translation that untie to the equivalent searching of a word or expression but for the equivalent more emphasized on a broader level than the sentence.

Table 1. Translation Method

\begin{tabular}{|c|c|}
\hline \multicolumn{2}{|c|}{ Translation Method } \\
\hline Free translation method & 6 method \\
\hline Semantic translation method & 5 method \\
\hline Literal translation method & 5 method \\
\hline Adaptation translation method & 2 method \\
\hline
\end{tabular}

Furthermore, we conclude from the poem The Bicycle Rider, and the first method used the free translation method; there are six free translations in the poem because the translation uses free words, namely the word 'clumsy,' 'slewie,' 'sagging gut,' 'bump and rise,' 'sweet indeed' 
Globish (An English-Indonesian journal for English, Education and Culture)

Vol. 11, No.1, January 2022,

P-ISSN: 2301-9913, E-ISSN: 2597-9132

DOI: http://dx.doi.org/10.31000/globish.v7i2

and then 'the sweets creeps out on his forehead.' The second method used the semantic method; there are five semantic methods in the poem because the translation of the words is flexible. Namely the words 'just like that,' 'when he brings the new bike,' 'the boy race after him,' and then 'they aim for the park.' The third method used the literal translation method; there are five translation methods in the poem. Because the word-for-word translation is the word from 'the bicycle rider,' 'No, it's for me,' 'he is aching already,' 'now, he feels as the boys feels,' and then 'it's a race for home.' Furthermore, the last method that is slightly furthermore in the poem is the adaptation method because there are two adaptation methods in these two poems. After all, the translation of the words is the most accessible, namely the words 'freest' alternative.

\section{CONCLUSION}

This poem tells about a father who buys a new bicycle and then tries to ride it in a park, but the person followed by many small children, which makes him feel nervous; he enjoys the moment when playing with his son so that the father feels like returning to his childhood. By reading and analyzing Pengayuh Sepeda by Tom W. Shapcott on Sapardi Djoko Damono's translation will bring the reader that translation correlates with the source language orientation because the source language will bring us to the other culture and how to translate the poem.

\section{REFERENCES}

Bell, R. T. (1993). Translation and Translating: Theory and Practice (2nd ed.). Longman Group UK Limited. https://doi.org/10.2307/416432

Blokh, M. Y., Asratyan, Z. D., \& Asratyan, N. M. (2019). Topic of the Imaginative Text and Its Philosophical and Linguistic Presentation. Journal of History Culture and Art Research, 8(2), 128. https://doi.org/10.7596/taksad.v8i2.2150

Coppers, S., van den Bergh, J., Luyten, K., Coninx, K., van der Lek-Ciudin, I., Vanallemeersch, T., \& Vandeghinste, V. (2018). Intellingo: An intelligible translation environment. Conference on Human Factors in Computing Systems - Proceedings, 2018-April. https://doi.org/10.1145/3173574.3174098

Dewi, H. D., \& Hidayat, R. S. (2020). The Effectiveness between Two Translation Assessment Models for English to Indonesian Translation of Undergraduate Students. Journal of Language and Literature, 20(2), 270. https://doi.org/10.24071/joll.v20i2.2622

Dinarty, A. (2019). The Use of Pocket Dictionary and Online Word-For-Word Translation on Reading Skill: An Experimental Study at Sman 4 Kota Bima Academic Year 2018/2019. International Journal of Multicultural and Multireligious Understanding, 6(5), 1015. https://doi.org/10.18415/ijmmu.v6i5.1221

Fitria, T. N. (2018). Translation Techniques Found in English to Indonesian Abstract Translation of Journal Edunomika 2018. ELITE: English and Literature Journal, 5(2). https://doi.org/https://doi.org/10.24252/elite.v5i2a4

House, \& Juliane. (2018). Translation: The Basics. Routledge.

Iordan, C. (2021). Definition of Translation, Translation Strategy, Translation Procedure, Translation Method, Translation Technique, Translation Transformation. In InterConf (pp. 473-485). https://doi.org/10.51582/interconf.19-20.02.2021.049

Jizzakh, N. U., \& Mamasharif, P. (2020). Transfer of Referential Meanings in Literary Translation. Mental Enlightenment Scientific-Methodological Journal, 2020(2), 10. https://uzjournals.edu.uz/tziuj/vol2020/iss2/10/

Kaharuddin. (2018). The Commucative Grammar Translation Method (A Practical Method to Teach Communication Skills of English). Eternal, 4(2). http://journal.uinalauddin.ac.id/index.php/Eternal/article/view/6292/5699 
Globish (An English-Indonesian journal for English, Education and Culture)

Vol. 11, No.1, January 2022,

P-ISSN: 2301-9913, E-ISSN: 2597-9132

DOI: http://dx.doi.org/10.31000/globish.v7i2

Läubli, S., Sennrich, R., \& Volk, M. (2018). Has Machine Translation Achieved Human Parity? A Case for Document-level Evaluation. http://arxiv.org/abs/1808.07048

Lomas, T. (2018). Translating Happiness (A Cross-Cultural Lexicon of Well-Being) (1st ed.). The MIT Press.

Millar, S. R. (2020). Openness, Closure, and Transformation in Proverb Translation. The Bible Translator, 71(1), 79-100. https://doi.org/10.1177/2051677019889651

Newmark, P. (1977). Communicative and Semantic Translation. Babel. Revue Internationale de La Traduction / International Journal of Translation, 23(4), 163-180. https://doi.org/10.1075/babel.23.4.07new

Newmark, P. (1988). A Textbook of Translation (1st ed.). Prentice-Hall International.

Newmark, P. (1993). Paragraphs on Translation (1st ed.). Multilingual Matters. https://doi.org/10.2307/329050

Nugraha, A., Nugroho, M. A. B., \& Rahman, Y. (2017). English-Indonesian translation methods in the short story A Blunder by Anton Chekhov. Indonesian EFL Journal, 3(1), 79-86. https://doi.org/https://doi.org/10.25134/ieflj.v3i1.656

Pan, R. (2012, April 21). Bengawan Solo. The Blog of Charles. https://charuzu.wordpress.com/2012/04/21/bengawan-solo/

Rahma, A., Kristina, D., \& Marmanto, S. (2018). Analisis Teknik Penerjemahan Adaptasi Dan Variasi Pada Subtitle Film Batman Versi Bahasa Jawa Mataraman. PRASASTI: Journal of Linguistics, 3(1), 13. https://doi.org/10.20961/prasasti.v3i1.19664

Robinson, D. (2012). Becoming a Translator (An Introduction to the Theory and Practice of Translation). In Routledge (3rd ed.). Routledge.

Shapcott, T. W. (1991). The Bicycle Rider. In R. F. Brissenden \& S. D. Damono (Eds.), Mendorong Jack Kunti Kunti (1st ed.). Yayasan Obor Indonesia.

Spahiu, I., \& Kryeziu, N. (2021). Contrastive Study of Grammar Translation Method and Direct Method in Teaching of English Language to Primary School Pupils. Linguistics and Culture Review, 5(S2), 1022-1029. https://doi.org/10.21744/lingcure.v5ns2.1663

Sutikno, E. U. (2019). Denotation and Connotation on "Pathetic Fairy Tale" by Saptarasa. An English-Indonesian Journal for English, Education and Culture, 7(2). https://doi.org/10.31000/globish.v7i2

Sutikno, E. U. (2021a). Memaknai Puisi Indonesia dan Amerika. Jurnal Membaca, 6(April), 8186. https://doi.org/http://dx.doi.org/10.30870/jmbsi.v6i1.11159

Sutikno, E. U. (2021b, February 27). Perihal Puisi (Untuk Pemula Banget!) / BantenNews.co.id Berita Banten Hari Ini. BantenNews.Co.Id. https://www.bantennews.co.id/perihal-puisiuntuk-pemula-banget/?ltclid=3a8aa0c6-9a66-4aae-bdb2-779a73a1a998

Tian, L., \& Zhu, C. (2020). Making Connections Through Knowledge Nodes in Translator Training. International Journal of Translation, Interpretation, and Applied Linguistics, 2(2), 15-29. https://doi.org/10.4018/ijtial.20200701.oa2

Zahrani, H. al. (2018). Idiomatic Translation Between English and Arabic: Cultural Differences. Journal of Language, Linguistics and Literature, 4(1), 1-7. http://www.aiscience.org/journal/allissues/j3l.html?issueId=70360404

Zain, M., · S., \& Wilson, R. (2019). Translation and Tourism (Strategies for Effective CrossCultural Promotion) (1st ed.). Sprinter Nature Singapore Ltd. https://doi.org/https://doi.org/10.1007/978-981-13-6343-6 Zbib, R., Hartmann, W., Jiang, Z., Zhao, L., DeYoung, J., Rivkin, N., Karakos, D., Huang, Z., Zhang, L., Schwartz, R., \& Makhoul, J. (2019). Neural-network Lexical Translation for Cross-lingual IR from Text and Speech. SIGIR 2019 - Proceedings of the 42nd International ACM SIGIR Conference on Research and Development in Information Retrieval, 645-654. https://doi.org/10.1145/3331184.33312 